\title{
Investigation of effective parameters on biomass and lipid productivity of Chlorella vulgaris
}

\author{
FAHIMEH SADAT MOHAMMADI ${ }^{1}$ \\ DARYUSH ARABIAN2* \\ RASSOUL KHALILZADEH ${ }^{1}$ \\ ${ }^{1}$ Department of Bioscience and Biotechnology \\ Malek-ashtar University of Technology, Tehran, Iran \\ ${ }^{2}$ Institute of Applied Science, Malek ashtar University \\ of Technology, Isfahan, Iran

\section{Correspondence:} \\ Daryush Arabian \\ E-mail:darabian@mut.ac.ir
}

Keywords: C. vulgaris, Lipid productivity, Light intensity and photoperiod, Response surface methodology
Received May 25, 2015.

Revised June 25, 2016.

Accepted June 30, 2016

\begin{abstract}
Background and purpose: In recent years, microalgae lipid has attracted considerable attention for biodiesel production due to its carbonneutral status and Chlorella vulgaris is one of the most interesting candidates.

Materials and methods: In the present study, initially, the effects of temperature and inorganic carbon source on $\mathrm{C}$. vulgaris microalgae were investigated in terms of biomass concentration, lipid content and productivity. Afterwards, one of the statistical experimental designs, response surface methodology was applied to find the optimum amount of light intensity and photoperiod that highly influence on microalgae growth and lipid content.

Results and conclusions: Results showed that $\mathrm{C}$. vulgaris could grow in a wide range of temperature $\left(25^{\circ} \mathrm{C}-35^{\circ} \mathrm{C}\right)$. The optimal temperature to produce maximum microalgae biomass and lipid was $30^{\circ} \mathrm{C}$ and the biomass production of $394 \mathrm{mg} / \mathrm{l}$ and lipid productivity of $6.07 \mathrm{mg} / \mathrm{l}$.d were obtained after 7 days of batch cultivation. Using a higher concentration of sodium carbonate, tenfold of control experiment, along with $0.03 \%$ carbon dioxide from the aeration could substantially enhance the microalgae growth rate $\left(0.66 \mathrm{~d}^{-1}\right)$, biomass production $(500 \mathrm{mg} / \mathrm{l})$ and lipid productivity $(7.34$ $m g / l . d)$. According to the results of experimental design, illumination of 3500 lux and photoperiod of 12:12 hour were the optimum amounts that led to a twofold increase in biomass and lipid productivity compared with unoptimized condition.
\end{abstract}

\section{INTRODUCTION}

The world is about to face an energy crisis because the global demand 1 for energy keeps growing and the fossil fuels on which the world still depends are finite and far from environmentally friendly. Therefore, it is essential to find sustainable alternative energy sources[1]. Among renewable energy sources, microalgae biomass has attracted much attention in recent years. Biomass of microalgae species, capable of producing useful chemicals such as fatty acids, starch, cellulose and so on, can be a favorable feedstock for producing a variety of renewable fuels, such as biodiesel, bioethanol, biohydrogen and biomethane[2]. Also microalgae species have faster growth rates in comparison to terrestrial oil crops because of their higher photosynthesis efficiency[3]. In addition, microalgae cultivation can be accompanied by the direct bio mitigation of $\mathrm{CO}_{2}$ caused by industrial activities or treatment of a variety of wastewater sources $[4,5]$. C. vulgaris is one of the most attractive microalgae for biodiesel production because of its high growth rate and 
suitable profile of fatty acids such as C16:0, C18:0, C16:1 and C18:1[6]. Nevertheless, one of the major bottlenecks for commercial applications of microalgae is the low lipid productivity that leads to high production cost[7]. Several studies have indicated that different nutritional conditions (e.g., concentration of carbon, nitrogen, phosphorous and iron source) and environmental parameters (e.g., temperature, light quality and quantity) significantly influence on biomass and lipid productivity of microalgae[8].

Temperature fluctuations have been found to alter the growth and lipid content of microalgae. However, variations of growth and lipid content differ from species to species. A twofold increase in the lipid content of $\mathrm{Nan}$ nochloropsis oculata from $7.90 \%$ to $14.92 \%$ was observed as the temperature rose from $20^{\circ} \mathrm{C}$ to $25^{\circ} \mathrm{C}$, while a temperature shift from $25^{\circ} \mathrm{C}$ to $30^{\circ} \mathrm{C}$ caused reduction of lipid content of C. vulgaris from $14.71 \%$ to $5.90 \%$ [9]. On the other hand, different concentrations of carbonate and bicarbonate ions can be used as an alternative to $\mathrm{CO}_{2}$ gas to solve the problem of the low solubility of $\mathrm{CO}_{2}$ in water and keep the DIC (dissolved inorganic carbon) concentration level high in the culture medium and thus achieving more biomass productivity[10]. Besides that, light energy is required to fix one carbon atom and subsequent biosynthesis. Light supply has a fundamental role in microalgae growth and light requirements depend greatly on species, culture depth and culture density. Illumination factors, including fluctuations in intensity and length of photoperiod highly influence microalgae growth and its biocomposition[11].

This study intends to examine the effects of temperature and carbonate concentration on cell concentration, cell growth rate, chlorophyll content, lipid content and productivity of C. vulgaris.

Furthermore, the amount of light intensity and photoperiod were optimized by employing a statistical experimental design in order to reach more biomass and lipid productivity.

\section{MATERIALS AND METHODS}

\section{Microalgae strain and growth conditions}

The freshwater microalgae strain investigated in this study was $C$. vulgaris which was obtained from National Inland Water Aquaculture Institute, Bandar Anzali. The microalgae was preserved and cultured in Z8 medium, containing the following components $(\mathrm{g} / \mathrm{l}): 0.25$ $\mathrm{MgSO}_{4} \cdot 7 \mathrm{H}_{2} \mathrm{O}, 0.467 \mathrm{NaNO}_{3}, 0.059 \mathrm{Ca}\left(\mathrm{NO}_{3}\right)_{2} \cdot 4 \mathrm{H}_{2} \mathrm{O}$, $0.031 \mathrm{NH}_{4} \mathrm{Cl}, 0.02 \mathrm{Na}_{2} \mathrm{CO}_{3}, 10 \mathrm{ml}$ of EDTANa 2 -Fe solution and $1 \mathrm{ml}$ of the Gaffron micronutrients solution. The Gaffron micronutrients solution contained ( $\mathrm{g} / \mathrm{l}): 3.1$ $\mathrm{H}_{3} \mathrm{BO}_{3}, 2.23 \mathrm{MnSO}_{4} .4 \mathrm{H}_{2} \mathrm{O}, 0.22 \mathrm{ZnSO}_{4} .7 \mathrm{H}_{2} \mathrm{O}, 0.088$ $\left(\mathrm{NH}_{4}\right)_{6} \mathrm{Mo}_{7} \mathrm{O}_{24} \cdot 4 \mathrm{H}_{2} \mathrm{O}, 0.146 \mathrm{Co}\left(\mathrm{NO}_{3}\right)_{2} \cdot 6 \mathrm{H}_{2} \mathrm{O}, 0.054$
$\mathrm{VOSO}_{4} \cdot 6 \mathrm{H}_{2} \mathrm{O}, 0.474 \mathrm{Al}_{2}\left(\mathrm{SO}_{4}\right)_{3} \mathrm{~K}_{2} \mathrm{SO}_{4} \cdot 2 \mathrm{H}_{2} \mathrm{O}, 0.198$ $\mathrm{NiSO}_{4}\left(\mathrm{NH}_{4}\right)_{2} \mathrm{SO}_{4} \cdot 6 \mathrm{H}_{2} \mathrm{O}, 0.154 \mathrm{Cd}\left(\mathrm{NO}_{3}\right)_{2} \cdot 4 \mathrm{H}_{2} \mathrm{O}, 0.037$ $\mathrm{Cr}\left(\mathrm{NO}_{3}\right)_{3} .7 \mathrm{H}_{2} \mathrm{O}, 0.033 \mathrm{Na}_{2} \mathrm{WO}_{4} \cdot 2 \mathrm{H}_{2} \mathrm{O}, 0.119 \mathrm{KBr}$, $0.083 \mathrm{KI}$. The EDTANa 2 -Fe solution contained $0.28 \mathrm{~g} / \mathrm{l}$ $\mathrm{FeCl}_{3}$ and $0.37 \mathrm{~g} / \mathrm{EDTANa}{ }_{2}[12$ ]. The microalgae strain was pre-cultured at $30^{\circ} \mathrm{C}$ under a light intensity of 40 $\mu \mathrm{mol} \mathrm{m} \mathrm{m}^{-2} / 2000$ lux (illuminated by $40 \mathrm{~W}$ white fluorescent lamps) on a light:dark cycle of 12:12 hour, an agitation rate of $130 \mathrm{rpm}$. An aeration rate of $0.5 \mathrm{vvm}$ with $0.03 \% \mathrm{CO}_{2}$ was continuously provided for all treatments of microalgae. All cultivations were performed in $500 \mathrm{ml}$ Erlenmeyer flasks containing $200 \mathrm{ml}$ of Z8 medium and $10 \%$ inoculation. Before inoculation, the $\mathrm{pH}$ of the medium was adjusted to 7 . All the cultures were incubated for 7 days. Every 24 h, liquid sample was collected in order to determine microalgae cell concentration, chlorophyll and lipid content. All samplings were carried out in triplicate for accuracy of the data.

\section{Determination of microalgae biomass concentration}

The growth of microalgae was monitored daily by optical density measurements at a wavelength of $600 \mathrm{~nm}$ (OD600nm) using a UV-vis spectrophotometer (Model U-2001, Hitachi, Tokyo, Japan). By correlating the optical density with the dry weight of biomass, a regression equation was obtained as follows (Eq. 1):

$$
\begin{gathered}
\text { Biomass concentration }(\mathrm{g} \text { dry cell } / \mathrm{l})= \\
=0.4216 \times \mathrm{OD}_{600},\left(\mathrm{R}^{2}=0.9815\right)
\end{gathered}
$$

The dry weight of microalgae was determined by collecting samples from culture medium. The samples were then centrifuged at $1500 \mathrm{~g}$ for 10 minutes by Eppendorf Centrifuge 5810R (Eppendorf Co., Ltd., Hamburg, Germany), then washed with double distilled water and dried at $70^{\circ} \mathrm{C}$ until constant weight.

\section{Determination of specific growth rate}

In order to calculate the specific growth rate $\left(\mu, \mathrm{d}^{-1}\right)$, dry cell weight was plotted against time on a logarithmic scale and the slope was calculated. The biomass productivity (P, $\left.\mathrm{mg} \mathrm{l}^{-1} \mathrm{~d}^{-1}\right)$ was calculated as follows (Eq. 2):

$$
\mathrm{P}=\left(\mathrm{X}_{2}-\mathrm{X}_{1}\right) /\left(\mathrm{t}_{2}-\mathrm{t}_{1}\right)
$$

Where $\mathrm{X}_{2}$ and $\mathrm{X}_{1}$ are biomass concentrations on days $t_{2}$ and $t_{1}$, respectively [13].

\section{Determination of chlorophyll a content}

For extraction of chlorophyll, $90 \%$ methanol was added to the samples collected by centrifugation. Then the samples were placed in Benmary for $50 \mathrm{~min}$ at $50^{\circ} \mathrm{C}$. In the next step, samples were centrifuged at $12000 \mathrm{~g}$ for $5 \mathrm{~min}$ and the absorbance of the supernatant was measured with regards to the blank at 650 and $665 \mathrm{~nm}$, re- 
spectively. The subsequent equation was used for calculation of chlorophyll a content (Eq. 3) [14]:

$$
\text { Chlorophyll a }(\mathrm{mg} / \mathrm{l})=16.5 \times \mathrm{A}_{665}-8.3 \times \mathrm{A}_{650}
$$

\section{Determination of lipid content and productivity}

For disruption of the microalgae cells obtained from the culture broth by centrifugation, $10 \%(\mathrm{w} / \mathrm{v}) \mathrm{NaCl}$ solution was used for 48 hours[6]. Then, according to Bligh and Dyer method, a mixture of chloroform and methanol $(1: 1 \mathrm{v} / \mathrm{v})$ was added to cells for lipid extraction. The lower layer containing the extracted lipid and chloroform solvent was separated. The solvent was removed by evaporation and lipid content was measured gravimetrically[15]. The lipid productivity $\left(\mathrm{P}_{\text {lipid }}\right)$ was determined based on the calculation indicated in (Eq. 4) [16]:

$$
P_{\text {lipid }}(\mathrm{mg} / 1 . \mathrm{d})=
$$

cumulative microalgae biomass production $(\mathrm{mg}) \times$ lipid content $(\%)$ working volume $(\mathrm{l}) \times$ cultivation time $(\mathrm{d})$

\section{Effect of temperature on C. vulgaris growth}

To study the effects of different temperatures on $C$. vulgaris growth, three different temperatures of 25,30 and $35^{\circ} \mathrm{C}$ were provided.

\section{Effect of carbonate concentration on C. vulgaris growth}

In this part of the study, the effect of different concentrations of sodium carbonate of $0.0002,0.002,0.02$ and $0.2 \mathrm{~g} / \mathrm{l}$ on growth and lipid content of $C$. vulgaris were examined.

\section{Experimental design examining the effect of light intensity and photoperiod}

The influence of light intensity and photoperiod on biomass productivity, lipid content and productivity of $C$. vulgaris was assessed through RSM (response surface methodology) coupled with CCD (central composite design). By applying this statistical design, polynomial re- gression between independent variables and dependent variables was obtained. In brief, CCD was performed with 2 chosen independent variables at 5 levels, as depicted in table 1 . The ranges of variables were selected based on the classical approaches obtained from literatures [7, 9-11]. 2 Factors, 5 levels CCD requires 13 sets of experiments which include 4 factorial points, 4 axial points and 5 replicates at the center point. A mathematical model, quadratic polynomial equation was obtained to describe the behavior of the system. The general form of the corresponding equation is described as follows (Eq. 5):

$$
\mathrm{y}_{\mathrm{i}}=\mathrm{b}_{0}+\sum_{\mathrm{i}=1}^{\mathrm{n}} \mathrm{b}_{\mathrm{i}} \mathrm{x}_{\mathrm{i}}+\sum_{\mathrm{i}=1}^{\mathrm{n}} \mathrm{b}_{\mathrm{ii}} \mathrm{x}_{\mathrm{i}}^{2}+\sum_{\mathrm{i}=1}^{\mathrm{n}-1} \sum_{j=i+1}^{\mathrm{n}} \mathrm{b}_{\mathrm{ij}} \mathrm{x}_{\mathrm{i}} \mathrm{x}_{\mathrm{j}}
$$

Where $y$ is the response variable, $b_{0}$ is the constant coefficient; $b_{\mathrm{i}}$ is the linear coefficient; $b_{\mathrm{ii}}$ is the quadratic coefficient and $b_{i j}$ is the second order interaction coefficient. $x_{i}$ and $x_{j}$ are the coded variables that were obtained according to the equation below (Eq. 6):

$$
\mathrm{x}_{\mathrm{i}}=\frac{\left(\mathrm{Xi}-\mathrm{X}_{0}\right)}{-\mathrm{X}_{\mathrm{i}}}
$$

Where in this equation, $\mathrm{x}_{\mathrm{i}}$ represents the coded value of the variable, $\mathrm{X}_{\mathrm{i}}$ is the real value of the variable, $\mathrm{X}_{0}$ is the real value of the variable at the center point and $\Delta \mathrm{X}_{\mathrm{i}}$ is the step change of the variable.

\section{RESULTS AND DISCUSSION}

\section{Effect of temperature on biomass production, chlorophyll content, lipid content and productivity of C. vulgaris}

In this study, the effects of different cultivation temperatures of $25^{\circ} \mathrm{C}, 30^{\circ} \mathrm{C}$ and $35^{\circ} \mathrm{C}$ on growth of C. vulgaris were examined. According to the results obtained (Table 2) and the growth curves of microalgae as depicted in Fig.1, the optimal temperature of growth is $30^{\circ} \mathrm{C}$. In comparison to $30^{\circ} \mathrm{C}$, microalgae exhibited $35.2 \%$ and $12.4 \%$ decrease in growth rate at $25^{\circ} \mathrm{C}$ and $35^{\circ} \mathrm{C}$, respectively. Chlorophyll a is a photosynthetic pigment found in microalgae and is a sensitive indicator of microalgae biomass. In this study, maximum chlorophyll a concentration was obtained at $30^{\circ} \mathrm{C}$.

Table 1. Experimental range and levels of light intensity and photoperiod according to the central composite design

\begin{tabular}{|lcccccrc|}
\hline Variable & Symbol & \multicolumn{5}{c}{ Range and levels } \\
\cline { 3 - 7 } & & -1.41 & -1 & 0 & +1 & +1.41 \\
\hline Light intensity (lux) & A & 1378 & 2000 & 3500 & 5000 & 5621 \\
Photoperiod (hr/hr) & B & $6.34 / 17.66$ & $8 / 16$ & $12 / 12$ & $16 / 8$ & $17.66 / 6.34$ \\
\hline
\end{tabular}


Table 2. Specific growth rate, biomass concentration, chlorophyll concentration, lipid content and productivity of C. vulgaris grown in different cultivation conditions

\begin{tabular}{|lccccc|}
\hline $\begin{array}{l}\text { Cultivation } \\
\text { temperature }\left({ }^{\circ} \mathrm{C}\right)\end{array}$ & $\begin{array}{c}\text { Specific growth } \\
\text { rate }(\mathrm{d}-1)\end{array}$ & $\begin{array}{c}\text { Biomass concentration } \\
(\mathrm{mg} / \mathrm{l})\end{array}$ & $\begin{array}{c}\text { Chlorophyll a } \\
\text { concentration }(\mathrm{mg} / \mathrm{l})\end{array}$ & $\begin{array}{c}\text { Lipid content } \\
(\%)\end{array}$ & $\begin{array}{c}\text { Lipid productivity } \\
(\mathrm{mg} / \mathrm{l} . \mathrm{d})\end{array}$ \\
\hline 25 & 0.3715 & 288 & 1.65 & 12.2 & 5.019 \\
30 & 0.5738 & 394 & 2.5 & 10.8 & 6.078 \\
35 & 0.5026 & 338 & 2 & 7.1 & 3.428 \\
\hline
\end{tabular}

In our study, reducing the growth temperature from $30^{\circ} \mathrm{C}$ to $20^{\circ} \mathrm{C}$ led to more accumulation of lipid content from $7.1 \%$ to $12.2 \%$ in microalgae cells. In another experiment, it was demonstrated that a decrease in temperature from $30^{\circ} \mathrm{C}$ to $25^{\circ} \mathrm{C}$ would induce the lipid accumulation in C. vulgaris CCAP211, 2.5 times higher [7]. It can be due to accumulation of reactive oxygen species „ROS” under the environmental stress of low temperature. High level of „ROS” causes cell components damaging, low growth rate and more accumulation of lipid content [7]. As stated in table 2, although $25^{\circ} \mathrm{C}$ caused the highest lipid content, but lower growth rate and thus low biomass production led to low lipid productivity. The highest lipid productivity was obtained under growth temperature of $30^{\circ} \mathrm{C}$.

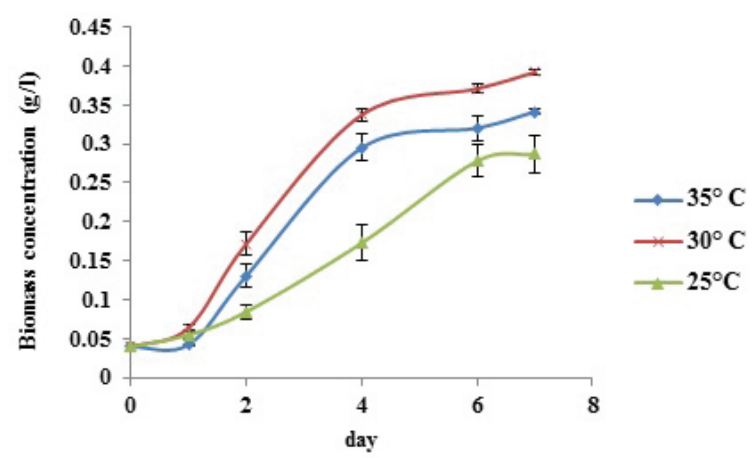

Fig. 1. Growth curves of C. vulgaris under different cultivation temperatures

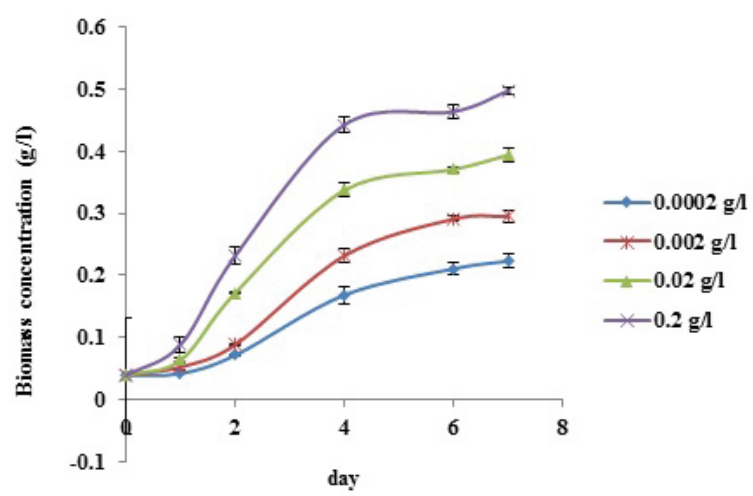

Fig. 2. Growth curves of C. vulgaris under different carbonate concentrations

\section{Effect of carbonate concentration on biomass production, chlorophyll content, lipid content and productivity of C. vulgaris}

A 10- to 100-fold decrease and 10-fold increase in sodium carbonate concentration compared to the control showed that various concentrations of dissolved inorganic carbon (DIC) can influence growth of the studied microalgae strain. Based on the results shown below in table 3 and Fig. 2, increasing the concentration of sodium carbonate in growth medium significantly stimulated the growth rate with the maximum specific growth rate of $0.669 \mathrm{~d}^{-1}$ obtained at $0.2 \mathrm{~g} / \mathrm{l}$ carbonate concentration. In the medium supplemented with $0.2 \mathrm{~g} / \mathrm{l}$ of $\mathrm{Na}_{2} \mathrm{CO}_{3}$ maximum biomass concentration of $0.5 \mathrm{~g} / \mathrm{l}$ was observed compared to the control experiment. Anjos et al. described in their study that the two enzymes with a pivotal role in carbon metabolism are carbonic anhydrase and Rubisco. Higher carbonate concentration causes the improvement of carboxylating activity and also the oxygenating activity of Rubisco will be decreased [18]. It is noteworthy that these variations caused slightly effect on lipid content.

Investigation of the effect of inorganic carbon source on microalgae growth has been the target of many researches [10,17]. In an experiment by Yeh et al [17], increasing bicarbonate concentration from $100 \mathrm{mg} / \mathrm{l}$ to $1200 \mathrm{mg} / \mathrm{l}\left(\mathrm{NaHCO}_{3}\right)$ in C. vulgaris ESP-31 culture led to more biomass production but further increase of bicarbonate concentration caused the marked increase in $\mathrm{pH}$ and thus slightly decrease in microalgae growth.

\section{Effect of light intensity and photoperiod on biomass production, lipid content and productivity of $\mathbf{C}$. vulgaris}

Final biomass concentration, lipid content and productivity of $C$. vulgaris cultivated under different light intensities and photoperiods are shown in table 5. It can be noted that $C$. vulgaris had the ability to grow under all the investigated levels. The application of regression analysis of the experimental data using Design Expert software, yielded the following quadratic regression equations for biomass production (Eq. 7), lipid content (Eq. 8) and lipid productivity (Eq. 9). 
Table 3. Specific growth rate, biomass concentration, chlorophyll a concentration, lipid content and productivity of C. vulgaris grown in medium with different carbonate concentrations

\begin{tabular}{|lccccc|}
\hline $\begin{array}{l}\text { carbonate concentration } \\
(\mathrm{g} / \mathrm{l})\end{array}$ & $\begin{array}{c}\text { Specific growth } \\
\text { rate }(\mathrm{d}-1)\end{array}$ & $\begin{array}{c}\text { Biomass concentration } \\
(\mathrm{mg} / \mathrm{l})\end{array}$ & $\begin{array}{c}\text { Chlorophll a concen- } \\
\text { tration }(\mathrm{mg} / \mathrm{l})\end{array}$ & $\begin{array}{c}\text { Lipid content }(\%) \\
\text { Lipid productivity } \\
(\mathrm{mg} / \mathrm{l} . \mathrm{d})\end{array}$ \\
\hline 0.0002 & 0.3388 & 221 & 1.4 & 10.5 & 3.315 \\
0.002 & 0.4302 & 300 & 1.6 & 10.2 & 4.371 \\
0.02 (control) & 0.5738 & 394 & 2.5 & 10.8 & 6.078 \\
0.2 & 0.6697 & 499 & 2.8 & 10.3 & 7.342 \\
\hline
\end{tabular}

Table 4.p-value of parameters in 3 models.

\begin{tabular}{|c|c|c|c|}
\hline Parameter & Biomass Production (mg/l) & Lipid content (\%) & Lipid Productivity (mg/l.d) \\
\hline Model & $<0.0001$ & $<0.0001$ & $<0.0001$ \\
\hline $\mathrm{A}=$ light intensity & 0.0010 & $<0.0001$ & 0.0002 \\
\hline $\mathrm{B}=$ photoperiod & 0.2412 & 0.1335 & 0.2309 \\
\hline $\mathrm{AB}$ & 0.0165 & 0.0087 & 0.0423 \\
\hline $\mathrm{A}^{2}$ & $<0.0001$ & $<0.0001$ & $<0.0001$ \\
\hline $\mathrm{B}^{2}$ & $<0.0001$ & 0.0036 & $<0.0001$ \\
\hline
\end{tabular}

Table 5. RSM design in actual level of variables and the responses for optimization of light intensity and photoperiod for autotropic growth of C. vulgaris

\begin{tabular}{|c|c|c|c|c|c|c|}
\hline \multirow[t]{2}{*}{ run } & \multirow[t]{2}{*}{ type } & \multicolumn{2}{|c|}{ Variables } & \multicolumn{3}{|c|}{ Responses } \\
\hline & & $\begin{array}{l}\text { Light intensity } \\
\text { (lux) }\end{array}$ & $\begin{array}{c}\text { Photoperiod } \\
(\mathrm{hr} / \mathrm{hr})\end{array}$ & $\begin{array}{l}\text { Biomass Production } \\
(\mathrm{mg} / \mathrm{l} . \mathrm{d})\end{array}$ & $\begin{array}{l}\text { Lipid Content } \\
(\%)\end{array}$ & $\begin{array}{l}\text { Lipid Productivity } \\
\text { (mg/l. d) }\end{array}$ \\
\hline 1 & Fact & 5000 & $16 / 8$ & 190 & 5.9 & 1.868 \\
\hline 2 & Axial & 3500 & $6.34 / 17.66$ & 390 & 11.8 & 7.67 \\
\hline 3 & Axial & 5621 & $12 / 12$ & 150 & 4 & 1 \\
\hline 4 & Axial & 1378 & $12 / 12$ & 300 & 10.4 & 5.2 \\
\hline 5 & Fact & 5000 & $8 / 16$ & 270 & 7.5 & 3.375 \\
\hline 6 & Axial & 3500 & $17.65 / 6.35$ & 500 & 11 & 9.166 \\
\hline 7 & Center & 3500 & $12 / 12$ & 660 & 12 & 13.2 \\
\hline 8 & Center & 3500 & $12 / 12$ & 630 & 12.3 & 12.915 \\
\hline 9 & Fact & 2000 & $8 / 16$ & 350 & 10.3 & 6.008 \\
\hline 10 & Center & 3500 & $12 / 12$ & 670 & 12.2 & 13.623 \\
\hline 11 & Fact & 2000 & $16 / 8$ & 430 & 11.3 & 8.098 \\
\hline 12 & Center & 3500 & $12 / 12$ & 670 & 12.5 & 13.958 \\
\hline 13 & Center & 3500 & $12 / 12$ & 640 & 12.5 & 13.333 \\
\hline
\end{tabular}

Biomass Production $(\mathrm{mg} / \mathrm{l})=$ $=0.65-0.062 \mathrm{~A}+0.014 \mathrm{~B}-0.05 \mathrm{AB}-0.22 \mathrm{~A}^{2}-0.11 \mathrm{~B}^{2}$

Lipid Content $(\%)=$

$$
\text { 12.3-2.16A-0.22B-0.65AB-2.69 } \mathrm{A}^{2}-0.59 \mathrm{~B}^{2}
$$

Lipid Productivity $(m g / l . d)=$

$$
\begin{gathered}
=0.013-1.85 \times 10^{-3} \mathrm{~A}+3.37 \times 10^{-4} \mathrm{~B}-9.017 \times 10^{-4} \mathrm{AB}- \\
-5.38 \times 10^{-3} \mathrm{~A}^{2}-2.72 \times 10^{-3} \mathrm{~B}^{2}
\end{gathered}
$$

Where $\mathrm{A}$ and $\mathrm{B}$ are the coded terms for the two independent variables denoted as light intensity and photope- 

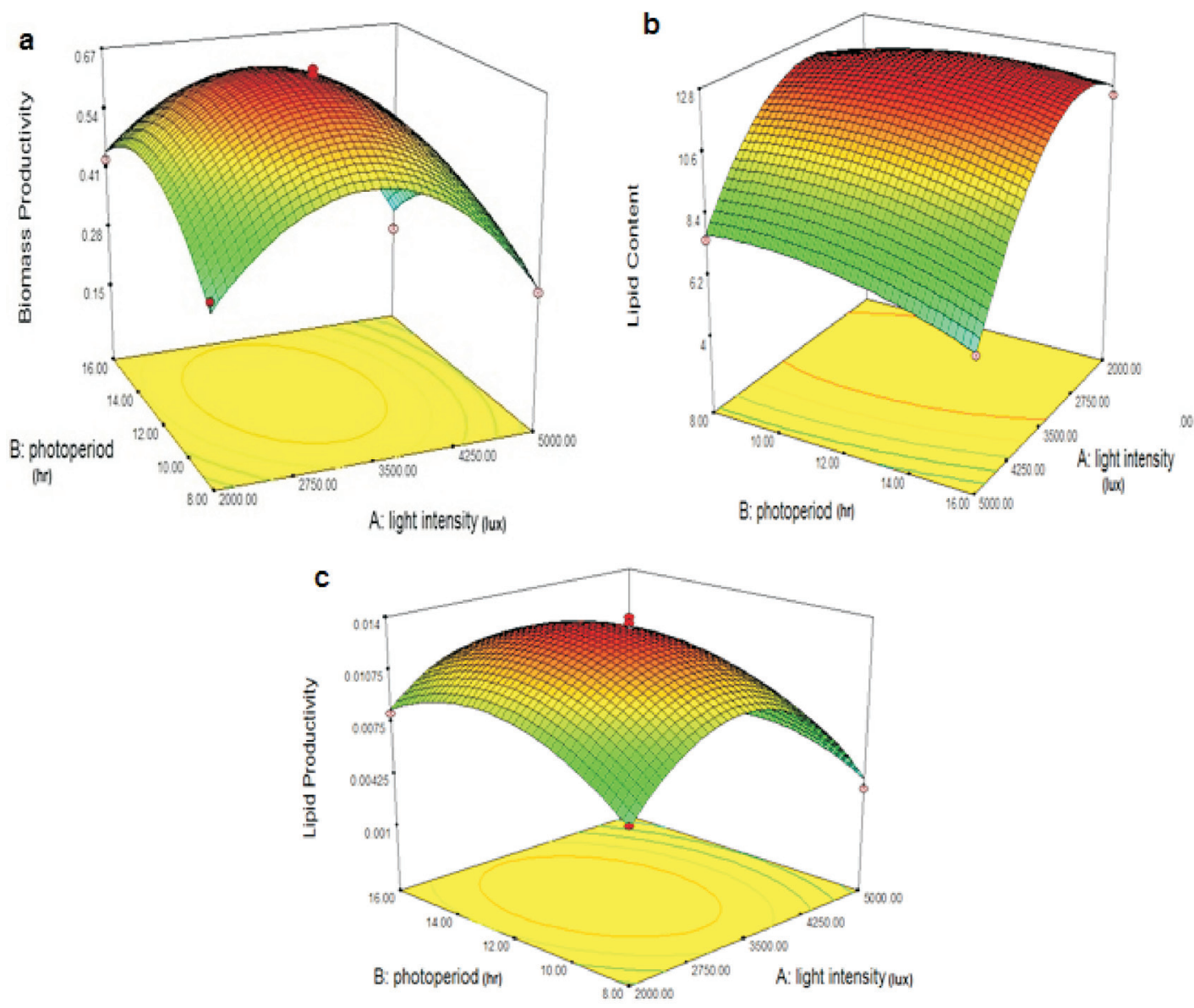

Fig 3. The response surface plot showing the effects of light intensity and photoperiod on biomass production (a), lipid content (b) and lipid productivity (c) by C. vulgaris.

riod, respectively. The $\mathrm{p}$-value from the analysis of variance (ANOVA) shows the significance of each variable. Variables with p-value less than 0.05 are significant.

The p-value of each variable for models is given in table 4. These amounts imply that the models are significant. The predicted $\mathrm{R}^{2}$ ( 0.97 for Eq. 7 and 0.98 for Eq. 8 and 0.97 for Eq. 9) agreed well with the adjusted model $\mathrm{R}^{2}$ (0.89 for Eq. 7 and 0.93 for Eq. 8 and 0.91 for Eq. 9), suggesting a close correlation between the observed values and the predicted values.

Results obtained from the graphs by central composite design showed that light intensity and photoperiod have considerable effects on microalgae biomass concentration and lipid productivity. In fact there is a correlation between light energy captured and carbon fixation which eventually causes variations in biomass production. According to Fig.3.a when the light intensity is increased from 2000 lux to 3500 lux, C. vulgaris exhibits maximum biomass production of $670 \mathrm{mg} / \mathrm{l}$ and when the light intensity is further increased up to 5000 lux, a reduction in biomass production is observed. The light saturation phase is around 3500 lux. At light intensity of 2000 lux, photo limitation and at light intensity of 5000 lux, photo inhibition caused lower biomass productivity. Below the light saturation phase, low light level is a growth limiting factor. Excessive light intensity damages photosynthetic machinery, primarily photosystem II (PSII), and causes photo inhibition that can limit microalgae growth[13]. Another result obtained from the Fig.3 is that under excessive light intensities, long light periods generally result in biomass loss while under low light intensities, long light periods result in more biomass production. Further increase in light intensity up to 5621 lux led to significant decline of microalgal growth, and later the cells dead. This result was easily visible because of color change of the cells from green to yellow.

As depicted in Fig.3.b. variations in light intensity cause significant alterations in lipid content of microalgae. In range of 2000 lux up to 4000 lux, lipid content varies between $10 \%$ up to $12 \%$ but further increasing of light intensity to 5000 lux and higher causes reduction of lipid content to $4 \%$. The reason might be due to the fact that the chloroplasts are mainly composed of lipids and high light intensity causes a reduction in the demand of chlo- 
roplastidial activity which ultimately results in the decrease in lipid content[19].

In this study, lipid productivity was applied to evaluate the efficiency of lipid production from microalgae. This critical variable considers the binary effects of lipid content and biomass productivity. As demonstrated in Fig 3.c. the maximum lipid productivity of $13.95 \mathrm{mg} / \mathrm{l}$.d will be obtained under illumination of 3500 lux and light/ dark cycle of 12:12 hr. This amount is approximately twofold of obtained productivity under unoptimized conditions.

\section{CONCLUSION}

The examination of temperature and carbonate concentration variations in $C$. vulgaris cultivation indicated that biomass and lipid productivity are strongly influenced by these variables. Through the range of $25-35^{\circ} \mathrm{C}$, at $30^{\circ} \mathrm{C}$, microalgae reached to maximum lipid productivity of $6.07 \mathrm{mg} / \mathrm{l} . \mathrm{d}$. Also tenfold increase in carbonate concentration caused maximum lipid productivity of 7.34 $\mathrm{mg} / \mathrm{l} . \mathrm{d}$.

Light is another key factor influencing biomass and lipid productivity and in indoor conditions, it is necessary to apply an optimum light exposure regime. In this study, by employing RSM coupled with CCD, the optimum amounts of light intensity and photoperiod were 3500 lux and 12:12 hr, respectively. Under this condition, lipid productivity reached to $13.958 \mathrm{mg} / \mathrm{l}$.d that is twofold of lipid productivity under non-optimized conditions.

\section{REFERENCES}

1. LAM M K, LEE K T 2012 Microalgae biofuels: a critical review of issues, problems and the way forward, Biotechnology Advances. 30: 673-690. http://dx.doi.org/10.1016/j.biotechadv.2011.11.008

2. COSTA J A V, DE MORAIS M G 2011 The role of biochemical engineering in the production of biofuels from microalgae, Bioresource Technology. 102: 2-9.

http://dx.doi.org/10.1016/j.biortech.2010.06.014

3. RAWAT I, RANJITH KUMAR R, MUTANDA T, BUX F 2013 Biodiesel from microalgae: A critical evaluation from laboratory to large scale production, Applied energy. 103: 444-467. http://dx.doi.org/10.1016/j.apenergy.2012.10.004

4. EBRAHIMIAN A, KARIMINIA H-R, VOSOUGHI M, 2014 Lipid production in mixotrophic cultivation of Chlorella vulgaris in a mixture of primary and secondary municipal wastewater, Renewable Energy. 71: 502-508.

http://dx.doi.org/10.1016/j.renene.2014.05.031

5. PIRES J CM, ALVIM-FERRAZ M C M, MARINS F G, SIMÓES M 2012 Carbon dioxide capture from flue gases using microalgae: Engineering aspects and biorefinery concept, Renewable and Sustainable Energy Reviews. 16: 3043-3053.

http://dx.doi.org/10.1016/j.rser.2012.02.055
6. SAFI C, ZEBIB B, MERAH O, PONTALIER P-Y, VACA-GARCIA C 2014 Morphology, composition, production, processing and applications of Chlorella vulgaris: A review, Renewable and Sustainable Energy Reviews. 35: 265-278.

http://dx.doi.org/10.1016/j.rser.2014.04.007

7. XIN L, HING-YING H, YU-PING Z 2011 Growth and lipid accumulation properties of a freshwater microalga Scenedesmus sp. under different cultivation temperature, Bioresource Technology. 102:3098-3102. http://dx.doi.org/10.1016/j.biortech.2010.10.055

8. MATA T M, MARTINS A A, CAETANO N S 2010 Microalgae for biodiesel production and other applications: A review, Renewable and Sustainable Energy Reviews. 14: 217-232.

http://dx.doi.org/10.1016/j.rser.2009.07.020

9. CONVERTI A, CASAZZA A A, ORTIZ E Y, PEREGO P, DEL BORGHI M 2009 Effect of temperature and nitrogen concentration on the growth and lipid content of Nannochloropsis oculata and Chlorella vulgaris for biodiesel production, Chemical Engineering and Processing: Process Intensification. 48: 1146-1151. http://dx.doi.org/10.1016/j.cep.2009.03.006

10. LAM M K, LEE K T 2013 Effect of carbon source towards the growth of Chlorella vulgaris for $\mathrm{CO}_{2}$ bio-mitigation and biodiesel production, International Journal of Greenhouse Gas Control. 14: 169-176. http://dx.doi.org/10.1016/j.ijggc.2013.01.016

11. GEORGE B, PANCHA I, DESAI C, CHOKSHI K, PALIWAL C, GHOSH T, MISHRA S 2014 Effects of different media composition, light intensity and photoperiod on morphology and physiology of freshwater microalgae Ankistrodesmus falcatus $-A$ potential strain for bio-fuel production, Bioresource technology. 171: 367-374. http://dx.doi.org/10.1016/j.biortech.2014.08.086

12. KOTAI J 1972 Instructions for preparation of modified nutrient solution Z8 for algae, Norwegian Institute for Water Research, Oslo. 115.

13. ATTA M, IDRIS A, BUKHARI A, WAHIDIN S 2013 Intensity of blue LED light: A potential stimulus for biomass and lipid, Bioresource Technology. 148: 373-378.

http://dx.doi.org/10.1016/j.biortech.2013.08.162

14. FU W, GUDMUNDSSON O, FEIST A M, HERJOLFSSON G, BRYNJOLFSSON S, PALSSON B O 2012 Maximizing biomass productivity and cell density of Chlorella vulgaris by using lightemitting diode-based photobioreactor, Journal of Biotechnology. 161: 242-249. http://dx.doi.org/10.1016/j.jbiotec.2012.07.004

15. BLIGH E G, DYER W J 1959 A rapid method of total lipid extraction and purification, Canadian journal of biochemistry and physiology. 37: 911-917. http://dx.doi.org/10.1139/059-099

16. YEH K-L, CHANG J-S 2012 Effects of cultivation conditions and media composition on cell growth and lipid productivity of indigenous microalga Chlorella vulgaris ESP-31, Bioresource Technology. 105: 120-127. http://dx.doi.org/10.1016/j.biortech.2011.11.103

17. YES K L, CHANG J S 2010 Effect of light supply and carbon source on cell growth and cellular composition of a newly isolated microalga Chlorella vulgaris ESP-31, Engineering in Life Sciences. 10: 201-208. http://dx.doi.org/10.1002/elsc.200900116

18. ANJOS M, FERNANDES B D, VICENTE A A, TEIXEIRA J A, DRAGONE G 2013 Optimization of $\mathrm{CO}_{2}$ bio-mitigation by Chlorella vulgaris, Bioresource Technology. 139: 149-154. http://dx.doi.org/10.1016/j.biortech.2013.04.032

19. DAS P, LEI W, AZIZ S S, OBBARD J P 2011 Enhanced algae growth in both phototrophic and mixotrophic culture under blue light, Bioresource Technology. 102 : 3883-3887. http://dx.doi.org/10.1016/j.biortech.2010.11.102 
